4. Гиляров А. Человек и животные: этика отношений // Любовь к природе. Материалы международной школы-семинара «Трибуна - 6». - Киев, 1997. - С. 129-137.

5. Гуляницкая Л. Возрастные особенности содержания понятия «природы» у школьников. - Даугавпилс, 1994. - С. 32-34.

6. Золотухина-Аболина Е.В. Современная этика: Учебное пособие для студентов вузов. - 3-е изд., перераб. и доп. - М.: ИКЦ «МарТ», 2005. - С. 402-411.

7. Лихачев Д.С. Экология - проблема нравственная // Наше наследие. - М., 1991. - № 1. - С. 3-7.

8. Мир на пороге XXI столетия / Под ред. В.И. Купцова. - Чебоксары: Клио, 1993. - 280 с.

9. Новиков А.М. Российское образование в новой эпохе: парадоксы наследия, векторы развития. - М.: Эгвес, 2000. - С. 71-78.

10. Ожегов С.И., Шведова Н.Ю. Толковый словарь русского языка: 80000 слов и фразеологических выражений / Российская АН.; Российский фонд культуры; - 2-е изд., испр. и доп. - М.: АЗЬ, 1994. - С. 570-571.

11. Поттер В.Р. Биоэтика: мост в будущее. - Киев: Изд. Вадим Карпенко, 2002. - 216 с.

12. Соколов В.Е. Фундаментальные биологические и экологические исследования. Вестник РАН, 1994. - Т. 64. - № 9. - С. 797-809.

13. Толстова О.И. Из опыта биоэтического воспитания студентов в харьковской государственной зооветеринарной академии // Биоэтика - путь к мировым стандартам: тезисы докл. II Международного симпозиума. - Харьков, 2005. - С. 188-189.

14. Харченко Л.Н., Горовая В.И., Сотникова Н.Н. Современное биологическое образование. Теоретический и технологический аспекты. - М.:Илекса - Ставрополь: Сервисшкола, 2005. - 320 с.

15. Швейцер А. Культура и этика / пер. с нем. - М.: Прогресс, 1973.- 344 с.

16. Экологическое образование: опыт России и Германии. - М.: Горизонт, 1997. -512 с.

17. Ясвин В.А. Психология отношения к природе. - М.: «Смысл», 2000. - С. 219-223.

18. Haan G. de: Okologie-Handbuch Sekundarstufe l: sieben Umweltthemen in nichtmathematischnaturwissenschaftlichen Fachern. - Weinheim; Basel: Beltz, 1994. - 242 s.

19. Mertens G. Umwelterziehung: eine Grundlegung ihrer Ziele. 3. Aufl. Paderborn; - Munchen; Wien; Zurich: Schoningh, 1995. - S. 233.

20. Weizsacker E.U. von Erdpolitik: Okologische Realpoitik an der Schwelle zum

21. Jahrhundert der Umwelt. Darmstadt: Wiss. Buchges. 1990. XIII. S. 9.

\title{
Сопова O.B. \\ Готовность будущих педагогов к инклюзивной практике в школе
}

Новосибирский государственный педагогический университет (Россия, Новосибирск)

doi: $10.18411 / l j-28-02-2018-28$

idsp: 000001:lj-28-02-2018-28

\section{Аннотация}

В статье рассматриваются понятие и структура инклюзивной готовности педагогов. Представлены результаты исследования уровня эмоционального и когнитивного компонентов готовности к работе в инклюзивном образовании будущих учителей иностранного языка.

Ключевые слова: инклюзивная готовность, эмоциональный компонент инклюзивной готовности, когнитивный компонент инклюзивной готовности.

В настоящее время все больше детей с ограниченными возможностями здоровья становятся участниками совместного образовательного процесса в условиях учреждений общего образования, что чрезвычайно актуализирует проблему готовности системы образования в целом и каждого педагога к работе в новых условиях.

Сенситивным периодом при формировании профессиональных качеств и компетенций у педагога является в период обучения в вузе. «Профессиональная подготовка учителя начинается в стенах вуза. И от профессиональных установок (ценностей), которые формирует система высшего профессионального образования, создавая условия для поиска личностного смысла профессии, зависит отношение студента к педагогической деятельности, его способность к формированию личностнопрофессиональных качеств» [3, с. 8]. 
Целью нашего исследования являлось определение у будущих учителей уровня профессиональной готовности к педагогической деятельности в условиях инклюзии.

В работах разных авторов рассматривается целый спектр важнейших характеристик профессиональной готовности учителей к педагогической деятельности: от ценностно-смысловых ориентиров [4] и психологических установок [2], до общепедагогических и специальных компетенций [5].

Готовность педагога к работе в условиях инклюзивного образования (инклюзивная готовность) определяется в науке как сложное интегральное субъектное качество личности, опирающееся на комплекс компетенций и определяющее возможность эффективной профессионально-педагогической деятельности в актуальных условиях [5].

В структуру инклюзивной готовности педагога, по мнению В.В. Хитрюк, входят следующие компоненты:

- когнитивный (восприятие и осознание инклюзивного образования, его концептуальной идеи, представления об организации и содержании образовательного процесса в условиях инклюзивного образования);

- эмоциональный (аффективные реакции и эмоциональная оценка (чувства, переживания), связанные с инклюзивным образованием, детьми с особыми образовательными потребностями);

- мотивационно-конативный (побудители непосредственного выражения установки в профессиональном поведении (мотивы, намерения, ценности и др.), готовность к проявлению компетентности, а также намерения, планы, замыслы действий);

- коммуникативный (способность педагога организовывать взаимодействие и общение с участниками инклюзивного образовательного пространства);

- рефлексивный (анализ собственной педагогической деятельности, анализ деятельности обучающихся, анализ взаимодействия педагога и детей в образовательном процессе, анализ результатов образовательного процесса) [5].

С учётом данных структурных компонентов нами изучалась готовность будущих учителей иностранного языка инклюзивной практике.

Респондентами явились студенты 3 курса, обучающиеся на факультете иностранных языков ФГБОУ ВО «Новосибирский государственный педагогический университет». По учебному плану по направлению подготовки (44.03.01 Педагогическое образование) в 5 семестре предусмотрена учебная дисциплина «Основы инклюзивного образования» [1], в рамках которой формируются компетенции необходимые для будущих учителей инклюзивного пространства.

Диагностика инклюзивной готовности будущих педагогов будет осуществляться в 2 этапа.

Первый этап - до обучения по дисциплине «Основы инклюзивного образования», второй - после изучения данной дисциплины. Тем самым мы планируем выявить динамику формирования инклюзивной готовности будущих учителей.

В данной статье мы представляем результаты первого этапа диагностики, которая осуществлялась с помощью методики «Сформированность компонентов инклюзивной готовности будущих педагогов», разработанной В.В. Хитрюк [5].

Суммируя ответы студентов на предложенные вопросы, мы получили следующие результаты:

- большинство респондентов принимают идею инклюзивного образования (93\%), однако, при этом 42\% будущих учителей не хотят думать о том, что будут работать в инклюзивной школе, а $64 \%$ - не представляют себя в роли учителя (воспитателя) инклюзивного класса (группы); 
- 69\% опрошенных студентов осознают психологическую неготовность к работе с «особыми» детьми в условиях инклюзии;

- у довольно большой часть будущих педагогов не сформировано принятие детей с ограниченными возможностями здоровья, готовность с ними работать (14,5 \% - равнодушны к детям с особенностями психофизического развития; 4\% испытывают психологическую неприязнь к детям с особенностями психофизического развития и не могут её преодолеть; $26 \%$ эмоционально не могут принять всех детей).

До изучения специальной дисциплины по инклюзивному образованию:

- $53 \%$ респондентов не считают, что инклюзия - это будущее массового образования;

- почти 1/6 часть отвечавших (16\%) уверены в том, что есть «необучаемые» дети;

- 94,5\% - не знают психолого-педагогические характеристики «особых» детей;

- 67\% будущих учителей считают, что есть категория детей, которые не могут находиться с обычными детьми;

- 71\% студентов считают, что дети с типичным развитием не хотят взаимодействовать с «особыми» детьми;

- $20 \%$ - считают, что у всех «особых» детей есть нарушения познавательной деятельности.

Вывод, который можно сделать по данным диагностики, следующий: на третьем году обучения в вузе эмоциональный и когнитивный компоненты готовности будущих учителей иностранного языка к работе в условиях инклюзии имеет низкий уровень.

Надеемся, что изучение специальной дисциплины «Основы инклюзивного образования» станет одним из условий формирования инклюзивной готовности студентов.

$$
* * *
$$

1. Малиновская М.П., Чепель Т.Л. Основы инклюзивного образования: электронное учебно-методическое пособие. Новосибирск. 2017. - Режим доступа: https://lib.nspu.ru/views/library/68725/web.php .

2. Митина Л.М. Психология профессионального развития учителя. - М.: Флинт, Московский психологосоциальный институт, 1998. - 200 с.

3. Федосеева И.А., Малиновская М.П. Образ учителя в системе современного образования // Гуманизация образования. - 2014. - № 5. - С. 6-13.

4. Федосеева И.А., Малиновская М.П. Феномен учительства в проблематике студенческих исследований // Научно-педагогическое обозрение. - 2014. - № 3 (5). - С. 52-57.

5. Хитрюк В.В. Готовность педагогов к работе в условиях инклюзивного формирования // Вестник Чувашского государственного педагогического университета имени И.Я. Яковлева. - 2013. - № 3 (79) C. 189-194. 